\title{
Association of Serotonin 1A Receptor Polymorphism with Variation in Health-Related Quality of Life in Korean Hemodialysis Patients
}

\author{
Hyeong Cheon Park', Sunyoung Park ${ }^{2}$, Hoon Young Choi', Jung Eun Lee ${ }^{3}$, \\ Hae Yeul Park', Seok-hyung Kim¹, Sung Kyu Ha', and Jeong-Ho Seok ${ }^{2} \bowtie$ \\ ${ }^{1}$ Department of Internal Medicine, Gangnam Severance Hospital, Institute for Vascular and Metabolic Research, Yonsei University \\ College of Medicine, Seoul, Republic of Korea \\ 2Department of Psychiatry, Gangnam Severance Hospital, Institute for Behavioral Science in Medicine, Yonsei University College of Medicine, \\ Seoul, Republic of Korea \\ ${ }^{3}$ Department of Internal Medicine, Yongin Severance Hospital, Yonsei University College of Medicine, Yongin, Republic of Korea
}

\begin{abstract}
Objective Hemodialysis patients may have psychological distress and reduced quality of life (QoL) related to chronic physical health problems. Genetic polymorphisms associated with reduced QoL in hemodialysis patients. The aim of this study was to investigate the relationship between genetic polymorphisms and variation in health-related QoL in Korean hemodialysis patients.

Methods The 36-item Short-Form Health Survey and the Korean Hospital Anxiety and Depression Scale were used to assess health-related QoL and psychological distress, respectively. Twenty hundred and five clinically stable patients from 6 hemodialysis centers have participated with informed consents. Sociodemographic factors, clinical factors, and genotypes of serotonin 1A receptor, brain-derived neurotrophic factors, and glucocorticoid receptor were assessed. Independent t-tests, correlation analyses, multiple regression analyses were performed for statistical analyses.

Results The serotonin 1A receptor CC genotype group showed significantly higher physical and mental QoL levels than those with the GG/GC genotypes. In the final linear regression analysis, serotonin 1A receptor CC genotype was significantly associated with positive physical and mental QoL levels.

Conclusion Serotonin 1A receptor polymorphism, as well as age and depression, were significantly associated with mental and physical QoL in hemodialysis patients. Functional activity in the serotonin receptor system may have a modulating effect on health-related QoL in hemodialysis patients.

Psychiatry Investig 2017;14(4):506-512
\end{abstract}

Key Words Depression, Hemodialysis, Quality of life, Serotonin 1A receptor polymorphism.

\section{INTRODUCTION}

Hemodialysis is the most common renal replacement therapy for patients with end-stage renal disease (ESRD). ${ }^{1}$ Hemodialysis patients may suffer from psychological distress and reduced quality of life, which is related to chronic physical health problems. ${ }^{2}$

ESRD patients may also have several medical comorbidities that have a significant impact on their quality of life. ${ }^{3}$ Also,

Received: March 28, 2016 Revised: June 1, 2016

Accepted: June 22, 2016 Available online: March 14, 2017

$\triangle$ Correspondence: Jeong-Ho Seok, MD, PhD

Department of Psychiatry, Gangnam Severance Hospital, Yonsei University College of Medicine, 211 Eonju-ro, Gangnam-gu, Seoul 06273, Republic of Korea Tel: +82-2-2019-3343, Fax: +82-2-3462-4304, E-mail: johnstein@yuhs.ac

(a) This is an Open Access article distributed under the terms of the Creative Commons Attribution Non-Commercial License (http://creativecommons.org/licenses/bync/4.0) which permits unrestricted non-commercial use, distribution, and reproduction in any medium, provided the original work is properly cited. emotional distress, including anxiety and depression, may contribute to deterioration in quality of life of this patient group. ${ }^{2}$ C-reactive protein (CRP) level has been reported to be associated with chronic inflammatory status, which has been associated with depression. ${ }^{4}$

Genetic polymorphism in serotonin receptor, neurotrophic factor, and glucocorticoid receptor function is known to also be associated with anxiety and depression, which may undermine the quality of life of ESRD patients. Dysfunction of the serotonergic system of the central nervous system is involved in the pathogenesis of depressive illness. Patients with depression have fewer serotonin transporters and serotonin $1 \mathrm{~A}$ receptors (5- $\mathrm{HT}_{1} \mathrm{~A}$ receptors). ${ }^{5} \mathrm{~A}$ common promoter polymorphism (C-1019G; rs6295) of 5- $\mathrm{HT}_{1} \mathrm{~A}$ receptors gene (HTR1A) has been known to be associated with psychiatric illness such as major depression and suicide, ${ }^{6}$ and anxiety-depression prone personality traits. ${ }^{7}$ Brain-derived neurotrophic factor 
gene (BDNF) polymorphism in human (rs6265) is also known to be associated with major depression ${ }^{8}$ and antidepressant treatment outcome. ${ }^{9,10}$ Genetic polymorphism in FK506 binding protein 5 (FKBP5) has a stress-sensitive effect on its interactions with glucocorticoid receptor proteins, and such polymorphisms are known to be associated with anxiety and depression in various clinical populations. ${ }^{11,12}$ However, the relationship between these genetic polymorphisms associated with depression and anxiety, and the quality of life of ESRD patients has not yet been sufficiently investigated. ${ }^{13}$ The aim of this study was to investigate the relationship between genetic polymorphisms and other clinical characteristics, and the health-related variation in quality of life of Korean hemodialysis patients. We hypothesized that SNPs associated with vulnerability to emotional distress may have a significant relationship with decreased quality of life in the ESRD patients.

\section{METHODS}

\section{Subjects}

A total of 245 clinically stable patients ( 154 male/ 87 female) from 6 hemodialysis centers participated in this study with informed consent. The average age of the participants was $54.66( \pm 12.65)$ years, and the mean duration of education was $12.05( \pm 3.89)$ years. On average, participants had received hemodialysis for $86.51( \pm 74.28)$ months, and had $1.41( \pm 0.91)$ comorbid diseases. Serum CRP level, blood urea nitrogen, creatinine, and high-density lipoprotein (HDL) cholesterol levels were assessed and KT/V1 was calculated from pre- and post-dialysis blood specimens to evaluate the hemodialysis adequacy. $^{14}$

\section{Health-related quality of life and emotional distress assessment}

A 36-item Short-Form Health Survey (SF-36) was used to assess the health-related quality of life (QoL) of each participant. ${ }^{15}$ The 36 items of this short questionnaire measure eight variables: physical functioning (10 items), social functioning (two items), role limitation due to physical problems (four items), role limitation due to emotional problems (three items), mental health (five items), energy and vitality (four items), pain (two items), and general perception of health (five items). There is a single item on further changes in respondents' health over the past year. ${ }^{15}$ The eight variables are hypothesized to form two distinct higher-ordered clusters due to the physical and mental health variance that they have in common. ${ }^{16}$ The score of these two clusters were analyzed as variances of mental and physical QoL in this study. For each variable item scores were coded, summed, and transformed on to a scale from 0 (worst possible health state measured by the questionnaire) to 100 (best possible health state). The validity of the Koreanversion of SF-36 was tested in several studies. ${ }^{17,18}$ In addition, psychological distress, such as depression and anxiety, were assessed using the Hospital Anxiety and Depression Scale (HADS). ${ }^{19}$ This scale was divided into an anxiety subscale (HADS-A) and a depression subscale (HADS-D), both of which contained seven questionnaire items. ${ }^{20}$ All items are scored on a 4 point scale from 0 to 3 . The HADS was previously proven to measure the anxiety and depression validity in Korean population. ${ }^{21}$

\section{Genetic polymorphism}

Genetic polymorphism of HTR1A, BDNF, and glucocorticoid receptor (FKBP5) were assessed. For genotyping, genomic DNA was isolated from EDTA-pretreated venous blood samples. The DNA fragments of interest were amplified by using a polymerase chain reaction (PCR). Three SNPs, rs6295 in HTR1A, ${ }^{7}$ rs6265 in BDNF, ${ }^{22}$ rs9296158 in FKBP5, ${ }^{11}$ were selected from among HTR1A, BDNF, FKBP5 variants identified in dbSNP (http://www.ncbi.nlm.nih.gov/SNP) as having functional significance. These three SNPs were previously investigated with respect to vulnerability to emotional distress and reduction of QoL level. The genotyping was screened with a single-base primer extension assay using an ABI PRISM ${ }^{\circledR}$ SNaPshot ${ }^{\mathrm{TM}}$ Multiplex Kit (Thermo Fisher Scientific, Waltham, MA, USA) according to the manufacturer's instructions. Analyses were performed using Genemapper Software version 4.0 (Thermo Fisher Scientific).

\section{Statistical analyses}

Statistical analyses were done using the SPSS version 20 (IBM SPSS Statistics for Windows, Version 20.0. Armonk, NY: IBM Corp.). The testing for Hardy-Weinberg equilibrium was conducted using the chi-square test. Independent sample ttests were conducted to compare physical and mental QoL level depending on HTR1A, BDNF, FKBP5 genetic polymorphisms. Correlation analyses were also performed to observe relationships between QoL levels and clinical characteristics in hemodialysispatients. Finally, multiple linear regression analyses were conducted to find significant factors which contribute physical and mental QoL in hemodialysis patients. All the tests were two-sided and probability value (p) less than 0.05 was considered statistically significant.

\section{Ethics statement}

The study protocol was approved by the Institutional Review Board of Gangnam Severance Hospital, Yonsei University College of Medicine (IRB No. 3-2012-0176). Informed consent was confirmed by the IRB. 


\section{RESULTS}

For the HTR1A polymorphism, the most prevalent genotype was $\mathrm{GG}(\mathrm{n}=149,60.8 \%)$, followed by $\mathrm{GC}(\mathrm{n}=80,32.7 \%)$, and CC $(n=16,6.5 \%)$. For the BDNF Val66Met, the most prevalent genotype was GA ( $n=117,47.8 \%)$, followed by GG $(\mathrm{n}=82,33.5 \%)$, and CC $(\mathrm{n}=46,18.8 \%)$. In addition, for the FKBP5, CC ( $\mathrm{n}=115,46.9 \%)$ genotype was the most common, followed by CT $(n=106,43.3 \%)$, and TT $(n=24,9.8 \%)$. The genotype distribution of the HTR1A, BDNF and FKBP5 polymorphism was in accordance with the Hardy-Weinberg equilibrium $\left(\chi^{2}=1.34, \mathrm{p}=0.246, \chi^{2}=0.139, \mathrm{p}=0.709\right.$, and $\chi^{2}=0.0035$, $\mathrm{p}=0.953$, respectively).
The results of a comparison of the physical and mental QoL levels depending on genetic polymorphism were summarized in Figure 1. Individuals with the CC genotype of serotonin 1A receptor promoter (rs6295) had a significantly higher QoL levelthan those with the GG/GC genotypes (physical QoL $243.2 \pm 67.0$ vs. $199.3 \pm 78.3, \mathrm{t}=-2.12, \mathrm{df}=229, \mathrm{p}=0.035$; mental QoL 259.0 \pm 58.9 vs. $208.0 \pm 69.1, \mathrm{t}=-2.871, \mathrm{df}=231, \mathrm{p}=0.004)$. However, there was no significant difference between the genotypes of BDNF (GG vs. GA/AA: physical QoL 203.1 \pm 77.8 vs. 200.4 $\pm 79.6, \mathrm{t}=0.235, \mathrm{df}=229, \mathrm{p}=0.81$; mental QoL 211.5 \pm 68.9 vs. $211.5 \pm 71.3, \mathrm{t}=0.001, \mathrm{df}=231, \mathrm{p}=0.99)$ or glucocorticoid receptor polymorphism (CC/CT vs. TT: physical QoL 204.4 \pm 78.1 vs. 181.7 $\pm 77.6, \mathrm{t}=1.321, \mathrm{df}=229, \mathrm{p}=0.188$; mental $\mathrm{QoL} 212.8 \pm$
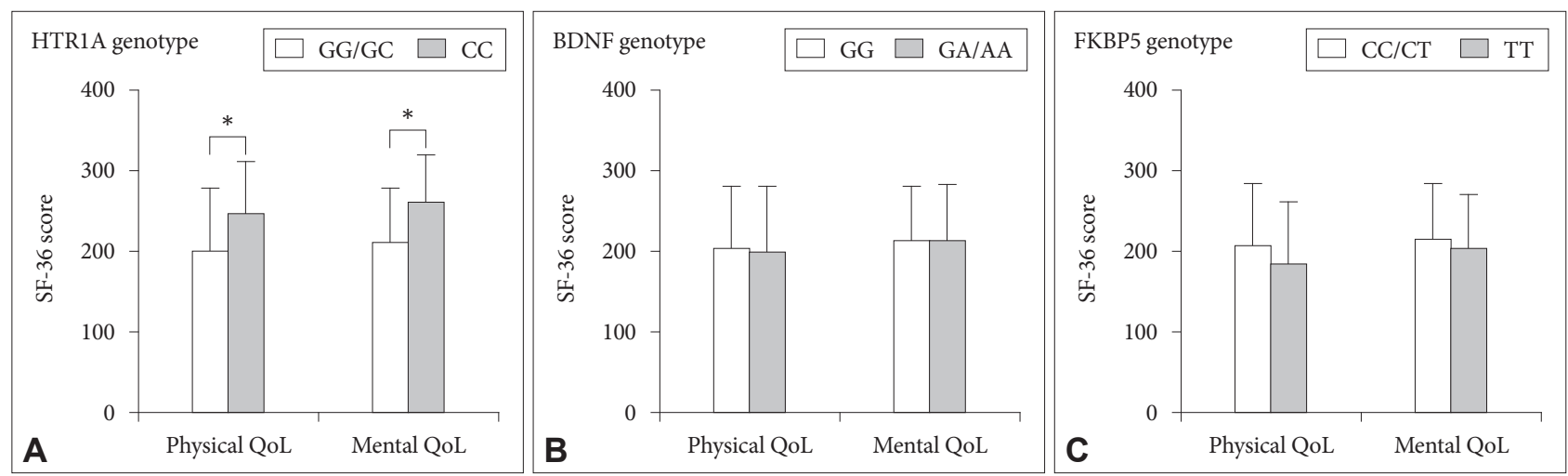

Figure 1. Comparison of physical and mental quality of life in hemodialysis patients according to genetic polymorphisms of serotonin $1 \mathrm{~A}$ receptor (5HTR1A), brain-derived neurotrophic factor (BDNF), and glucocorticoid receptor (FKBP5). ${ }^{*} \mathrm{p}<0.05$.

Table 1. Comparison of clinical characteristics of the hemodialysis patients depending on their genotypes

\begin{tabular}{|c|c|c|c|c|c|c|c|c|c|}
\hline & \multicolumn{3}{|c|}{ HTR1A (rs6295) } & \multicolumn{3}{|c|}{ BDNF (rs6265) } & \multicolumn{3}{|c|}{ FKBP5 (rs9296158) } \\
\hline & $\begin{array}{l}\text { GG/GC } \\
(\mathrm{N}=229)\end{array}$ & $\begin{array}{c}\mathrm{CC} \\
(\mathrm{N}=16)\end{array}$ & Sig. & $\begin{array}{l}\text { GA/AA } \\
(\mathrm{N}=163)\end{array}$ & $\begin{array}{c}\mathrm{GG} \\
(\mathrm{N}=82)\end{array}$ & Sig. & $\begin{array}{c}\mathrm{CC} / \mathrm{CT} \\
(\mathrm{N}=221)\end{array}$ & $\begin{array}{c}\mathrm{TT} \\
(\mathrm{N}=24)\end{array}$ & Sig. \\
\hline Age (year) & $\begin{array}{c}54.6 \\
(12.6)\end{array}$ & $\begin{array}{c}55.5 \\
(12.3)\end{array}$ & 0.76 & $\begin{array}{c}53.7 \\
(13.1)\end{array}$ & $\begin{array}{c}56.4 \\
(11.4)\end{array}$ & 0.13 & $\begin{array}{c}54.8 \\
(12.4)\end{array}$ & $\begin{array}{c}52.9 \\
(14.3)\end{array}$ & 0.47 \\
\hline Education (year) & $\begin{array}{l}12.0 \\
(3.8)\end{array}$ & $\begin{array}{l}12.5 \\
(4.2)\end{array}$ & 0.58 & $\begin{array}{l}11.9 \\
(3.8)\end{array}$ & $\begin{array}{l}12.2 \\
(3.9)\end{array}$ & 0.56 & $\begin{array}{l}12.1 \\
(3.8)\end{array}$ & $\begin{array}{l}10.6 \\
(4.1)\end{array}$ & 0.067 \\
\hline Anxiety & $\begin{array}{c}5.6 \\
(3.8)\end{array}$ & $\begin{array}{c}5.4 \\
(4.3)\end{array}$ & 0.84 & $\begin{array}{c}5.8 \\
(3.9)\end{array}$ & $\begin{array}{c}5.2 \\
(3.7)\end{array}$ & 0.23 & $\begin{array}{l}5.4^{*} \\
(3.7)\end{array}$ & $\begin{array}{l}7.1^{*} \\
(4.5)\end{array}$ & 0.044 \\
\hline Depression & $\begin{array}{c}7.5 \\
(4.0)\end{array}$ & $\begin{array}{c}6.3 \\
(4.0)\end{array}$ & 0.22 & $\begin{array}{c}7.4 \\
(3.9)\end{array}$ & $\begin{array}{c}7.5 \\
(4.1)\end{array}$ & 0.91 & $\begin{array}{c}7.3 \\
(3.9)\end{array}$ & $\begin{array}{c}8.6 \\
(4.9)\end{array}$ & 0.13 \\
\hline CRP & $\begin{array}{c}0.8 \\
(2.2)\end{array}$ & $\begin{array}{c}0.2 \\
(0.2)\end{array}$ & 0.40 & $\begin{array}{l}0.67 \\
(1.6)\end{array}$ & $\begin{array}{l}0.94 \\
(2.8)\end{array}$ & 0.42 & $\begin{array}{c}0.8 \\
(2.2)\end{array}$ & $\begin{array}{c}0.3 \\
(0.3)\end{array}$ & 0.31 \\
\hline KT/V1 & $\begin{array}{l}1.55 \\
(0.2)\end{array}$ & $\begin{array}{l}1.53 \\
(0.3)\end{array}$ & 0.80 & $\begin{array}{c}1.5 \\
(0.2)\end{array}$ & $\begin{array}{c}1.5 \\
(0.2)\end{array}$ & 0.82 & $\begin{array}{c}1.5 \\
(0.2)\end{array}$ & $\begin{array}{c}1.5 \\
(0.2)\end{array}$ & 0.99 \\
\hline Dialysis months & $\begin{array}{c}87.6 \\
(74.6)\end{array}$ & $\begin{array}{c}72.0 \\
(69.6)\end{array}$ & 0.41 & $\begin{array}{c}89.0 \\
(78.6)\end{array}$ & $\begin{array}{c}81.6 \\
(65.1)\end{array}$ & 0.47 & $\begin{array}{c}87.0 \\
(74.7)\end{array}$ & $\begin{array}{c}81.8 \\
(71.5)\end{array}$ & 0.74 \\
\hline No. of medical comorbidity & $\begin{array}{c}1.4 \\
(0.9)\end{array}$ & $\begin{array}{c}1.3 \\
(0.8)\end{array}$ & 0.88 & $\begin{array}{c}1.3 \\
(0.9)\end{array}$ & $\begin{array}{c}1.4 \\
(0.9)\end{array}$ & 0.33 & $\begin{array}{c}1.4 \\
(0.9)\end{array}$ & $\begin{array}{c}1.4 \\
(0.8)\end{array}$ & 0.96 \\
\hline
\end{tabular}

Independent sample t-tests were conducted. Data are presented as means (SD). ${ }^{*} \mathrm{p}<0.05$. CRP: C-reactive protein, KT/V1: an index for dialysis treatment adequacy, HTR1A: serotonin 1A receptor polymorphism, BDNF: brain derived neurotrophic factor polymorphism, FKBP5: glucocorticoid receptor polymorphism 
69.8 vs. $200.1 \pm 68.3, \mathrm{t}=0.829, \mathrm{df}=231, \mathrm{p}=0.40)$. The FKBP5 TT genotype group showed a slightly higher anxiety score compared to the CC/CT genotype group, but this result was clinically not significant (Table 1).

As shown in Table 2, physicalQoL level was found to be significantly correlated with age $(\mathrm{r}=-0.213, \mathrm{p}=0.001)$, anxiety $(\mathrm{r}=$ $-0.466, \mathrm{p}<0.001)$, depression $(\mathrm{r}=-0.582, \mathrm{p}<0.001)$, total hemodialysis duration $(\mathrm{r}=-0.231, \mathrm{p}=0.001)$, the number of comorbid medical illnesses $(\mathrm{r}=-0.191, \mathrm{p}=0.004)$, blood urea nitrogen $(\mathrm{r}=0.138, \mathrm{p}=0.038), \mathrm{CRP}(\mathrm{r}=-0.170, \mathrm{p}=0.028)$, and high-density lipoprotein (HDL) cholesterol levels $(r=0.169, \mathrm{p}=0.011)$. MentalQoL was significantly correlated with anxiety $(r=-0.619$, $\mathrm{p}<0.001)$, depression $(\mathrm{r}=-0.648, \mathrm{p}<0.001)$, total hemodialysis duration $(\mathrm{r}=-0.149, \mathrm{p}=0.027)$, the number of comorbid medical illnesses ( $\mathrm{r}=-0.17, \mathrm{p}=0.009)$, serum CRP $(\mathrm{r}=-0.175, \mathrm{p}=0.023)$, and HDL cholesterol levels ( $r=0.169, \mathrm{p}=0.011)$.

Anxiety and depression levels were significantly correlated with all variables of health related QoL assessed using SF-36. The number of comorbid medical illnesses was significantly inversely correlated with almost variables of QoL including physical function $(\mathrm{r}=-0.162, \mathrm{p}=0.012)$, bodily pain $(\mathrm{r}=-0.162$, $\mathrm{p}=0.012)$, general health $(\mathrm{r}=-0.237, \mathrm{p}<0.001)$, social functioning $(\mathrm{r}=-0.159, \mathrm{p}=0.014)$, emotional role limitation $(\mathrm{r}=-0.144$, $\mathrm{p}=0.025)$, and mental health $(\mathrm{r}=-0.139, \mathrm{p}=0.031)$. Total dialysis duration was also inversely correlated with physical role limitation $(\mathrm{r}=-0.213, \mathrm{p}=0.001)$, bodily pain $(\mathrm{r}=-0.188, \mathrm{p}=0.013)$, social functioning $(\mathrm{r}=-0.190, \mathrm{p}=0.004)$. CRP level was inversely correlated with bodily pain $(\mathrm{r}=-0.188, \mathrm{p}=0.013)$, general health $(\mathrm{r}=-0.167, \mathrm{p}=0.028)$, mental health $(\mathrm{r}=-0.152, \mathrm{p}=0.046)$. HDL cholesterol level showed a positive correlation with physical ( $\mathrm{r}=0.165, \mathrm{p}=0.011)$ and emotional role limitation $(\mathrm{r}=0.151$, $\mathrm{p}=0.020)$, bodily pain $(\mathrm{r}=0.194, \mathrm{p}=0.003)$, and social functioning $(\mathrm{r}=0.183, \mathrm{p}=0.005)$.

As shown in Table 3, physical QoL level was significantly associated with age $(B=-1.615, p=0.003)$, depression $(B=-8.568$, $\mathrm{p}<0.001)$, and medical comorbidity $(\mathrm{B}=-15.602, \mathrm{p}=0.045)$. Mental QoL level was associated with age $(B=-0.962, p=0.023)$, anxiety $(B=-5.606, p=0.001)$, and depression $(B=-5.437$, $\mathrm{p}=0.001)$. Furthermore, the CC genotype of serotonin $1 \mathrm{~A}$ receptor was positively correlated with both physical $(B=55.974$,

Table 2. Bivariate correlation analyses between health-related quality of life variables and clinical characteristicsin thehemodialysis patients

\begin{tabular}{|c|c|c|c|c|c|c|c|c|c|c|c|c|c|}
\hline & & Age & Edu. & $\begin{array}{c}\text { Comor- } \\
\text { bidity }\end{array}$ & $\begin{array}{c}\text { Dialys. } \\
\text { dur. }\end{array}$ & Anx. & Dep. & CRP & BUN & Cr. & T chol. & HDL-C & KT/V1 \\
\hline \multirow[t]{2}{*}{ QoL_phy. } & $\mathrm{r}$ & $-0.213^{*}$ & 0.109 & $-0.191^{*}$ & $-0.231^{*}$ & $-0.466^{*}$ & $-0.582^{*}$ & $-0.170^{*}$ & $0.138^{*}$ & 0.117 & 0.035 & $0.192^{*}$ & 0.055 \\
\hline & $\mathrm{p}$ & $0.001^{*}$ & 0.100 & $0.004^{*}$ & $0.001^{*}$ & $<0.001^{*}$ & $<0.001^{*}$ & $0.028^{*}$ & $0.038^{*}$ & 0.078 & 0.59 & $0.004^{*}$ & 0.45 \\
\hline \multirow[t]{2}{*}{ QoL_men. } & $\mathrm{r}$ & -0.115 & 0.088 & $-0.170^{*}$ & $-0.149^{*}$ & $-0.619^{*}$ & $-0.648^{*}$ & $-0.175^{*}$ & 0.067 & 0.074 & 0.056 & $0.169^{*}$ & 0.025 \\
\hline & $\mathrm{p}$ & 0.084 & 0.18 & $0.009^{*}$ & $0.027^{*}$ & $<0.001^{*}$ & $<0.001^{*}$ & $0.023^{*}$ & 0.31 & 0.26 & 0.40 & $0.011^{*}$ & 0.72 \\
\hline \multirow[t]{2}{*}{ PF } & $\mathrm{r}$ & $-0.315^{*}$ & 0.122 & $-0.162 *$ & -0.081 & $-0.232^{*}$ & $-0.387^{*}$ & -0.078 & $0.177^{*}$ & $0.244^{*}$ & -0.006 & 0.092 & -0.006 \\
\hline & $\mathrm{p}$ & $<0.001^{*}$ & 0.061 & $0.012^{*}$ & 0.22 & $<0.001^{*}$ & $<0.001^{*}$ & 0.30 & $0.006^{*}$ & $<0.001^{*}$ & 0.92 & 0.15 & 0.93 \\
\hline \multirow[t]{2}{*}{$\mathrm{RP}$} & $\mathrm{r}$ & $-0.196^{*}$ & 0.100 & -0.062 & $-0.213^{*}$ & $-0.334^{*}$ & $-0.369^{*}$ & -0.083 & 0.098 & 0.060 & 0.012 & $0.165^{*}$ & 0.039 \\
\hline & $\mathrm{p}$ & $0.003^{*}$ & 0.12 & 0.34 & $0.001^{*}$ & $<0.001^{*}$ & $<0.001^{*}$ & 0.27 & 0.13 & 0.35 & 0.85 & $0.011^{*}$ & 0.58 \\
\hline \multirow[t]{2}{*}{ BP } & $\mathrm{r}$ & -0.074 & 0.042 & $-0.162^{*}$ & $-0.183^{*}$ & $-0.479^{*}$ & $-0.531^{*}$ & $-0.188^{*}$ & 0.014 & -0.009 & 0.072 & $0.194^{*}$ & 0.085 \\
\hline & $\mathrm{p}$ & 0.25 & 0.52 & $0.012^{*}$ & $0.006^{*}$ & $<0.001^{*}$ & $<0.001^{*}$ & $0.013^{*}$ & 0.82 & 0.88 & 0.26 & $0.003^{*}$ & 0.22 \\
\hline \multirow[t]{2}{*}{ GH } & $\mathrm{r}$ & -0.015 & -0.028 & $-0.237^{*}$ & -0.125 & $-0.417^{*}$ & $-0.538^{*}$ & $-0.167^{*}$ & 0.073 & 0.012 & 0.074 & 0.106 & 0.064 \\
\hline & $\mathrm{p}$ & 0.81 & 0.67 & $<0.001^{*}$ & 0.063 & $<0.001^{*}$ & $<0.001^{*}$ & $0.028^{*}$ & 0.26 & 0.85 & 0.25 & 0.10 & 0.37 \\
\hline \multirow[t]{2}{*}{ VT } & $\mathrm{r}$ & $-0.147^{*}$ & $0.146^{*}$ & -0.084 & -0.104 & $-0.382^{*}$ & $-0.525^{*}$ & -0.124 & 0.099 & 0.088 & 0.061 & 0.091 & -0.005 \\
\hline & $\mathrm{p}$ & $0.025^{*}$ & $0.025^{*}$ & 0.19 & 0.11 & $<0.001^{*}$ & $<0.001^{*}$ & 0.10 & 0.13 & 0.17 & 0.34 & 0.16 & 0.94 \\
\hline \multirow[t]{2}{*}{ SF } & $\mathrm{r}$ & -0.072 & -0.001 & $-0.159^{*}$ & $-0.190^{*}$ & $-0.522^{*}$ & $-0.530^{*}$ & -0.132 & 0.045 & 0.064 & 0.040 & $0.183^{*}$ & 0.025 \\
\hline & $\mathrm{p}$ & 0.27 & 0.98 & $0.014^{*}$ & $0.004^{*}$ & $<0.001^{*}$ & $<0.001^{*}$ & 0.083 & 0.49 & 0.32 & 0.53 & $0.005^{*}$ & 0.72 \\
\hline \multirow[t]{2}{*}{$\mathrm{RE}$} & $\mathrm{r}$ & $-0.225^{*}$ & 0.105 & $-0.144^{*}$ & -0.092 & $-0.446^{*}$ & $-0.473^{*}$ & -0.123 & $0.130^{*}$ & $0.132^{*}$ & 0.010 & $0.151^{*}$ & 0.095 \\
\hline & $\mathrm{p}$ & $0.001^{*}$ & 0.10 & $0.025^{*}$ & 0.16 & $<0.001^{*}$ & $<0.001^{*}$ & 0.10 & $0.045^{*}$ & $0.041^{*}$ & 0.87 & $0.020^{*}$ & 0.17 \\
\hline \multirow[t]{2}{*}{ MH } & $\mathrm{r}$ & 0.034 & 0.086 & $-0.139 *$ & -0.081 & $-0.631^{*}$ & $-0.595^{*}$ & $-0.152^{*}$ & -0.025 & -0.038 & 0.087 & 0.114 & 0.017 \\
\hline & $\mathrm{p}$ & 0.60 & 0.19 & $0.031^{*}$ & 0.22 & $<0.001^{*}$ & $<0.001^{*}$ & $0.046^{*}$ & 0.70 & 0.55 & 0.18 & 0.081 & 0.81 \\
\hline
\end{tabular}

*Pearson Correlation analyses were performed. Statistically significant results. Edu: education level, Dialys. dur.: dialysis duration, Anx.: anxiety, Dep.: depression, CRP: C-reactive protein, BUN: blood urea nitrogen, Cr.: creatinine, T chol.: total cholesterol, HDL-C: high-density lipoprotein cholesterol, KT/V1: an index for dialysis treatment adequacy, QoL_phy.: global physical quality of life, QoL_men.: global mental quality of life, PF: physical functioning, RP: role limitation-physical, BP: bodily pain, GH: general health, VT: vitality, SF: social functioning, RE: role limitation-emotional, $\mathrm{MH}$ : mental health 
Table 3. Relationship between health-related quality of life levels and genetic polymorphisms, emotional distress, and clinical characteristics in hemodialysis patients

\begin{tabular}{|c|c|c|c|c|c|c|c|c|}
\hline & & Physical & ity of life & & & Mental & ty of life & \\
\hline & B & S.E & $\mathrm{t}$ & Sig. & B & S.E & $\mathrm{t}$ & Sig. \\
\hline Age & $-1.615^{*}$ & $0.533^{*}$ & $-3.031^{*}$ & $0.003^{*}$ & $-0.962^{*}$ & $0.417^{*}$ & $-2.309^{*}$ & $0.023^{*}$ \\
\hline Anxiety & -1.784 & 2.204 & -0.809 & 0.42 & $-5.606^{*}$ & $1.697^{*}$ & $-3.302^{*}$ & $0.001^{*}$ \\
\hline Depression & $-8.568^{*}$ & $1.929 *$ & $-4.441^{*}$ & $<0.001^{*}$ & $-5.437 *$ & $1.525^{*}$ & $-3.565^{*}$ & $0.001^{*}$ \\
\hline Medical comorbidity & $-15.602^{*}$ & $7.677^{*}$ & $-2.032^{*}$ & $0.045^{*}$ & -8.699 & 5.945 & -1.463 & 0.14 \\
\hline Dialys. dur. & -0.125 & 0.075 & -1.662 & 0.099 & -0.056 & 0.058 & -0.955 & 0.34 \\
\hline CRP & -1.481 & 2.623 & -0.565 & 0.57 & -1.151 & 2.036 & -0.565 & 0.57 \\
\hline $\mathrm{KT} / \mathrm{V}-1$ & -10.608 & 23.78 & -0.446 & 0.65 & -15.813 & 18.165 & -0.870 & 0.38 \\
\hline HTR1A_C & $55.974^{*}$ & $26.653^{*}$ & $2.100^{*}$ & $0.038^{*}$ & $51.145^{*}$ & $19.526^{*}$ & $2.619^{*}$ & $0.010^{*}$ \\
\hline BDNF_G & 10.924 & 12.903 & 0.847 & 0.39 & 3.914 & 10.007 & 0.391 & 0.69 \\
\hline FKBP5_T & -30.804 & 20.428 & -1.508 & 0.13 & -1.828 & 16.01 & -0.114 & 0.90 \\
\hline Model summary & & $10.143, \mathrm{p}$ & $1, \mathrm{R}^{2}=0$. & & & $=12.133, \mathrm{p}$ & $1, \mathrm{R}^{2}=0.5$ & \\
\hline
\end{tabular}

*multiple regression analyses were performed. Statistically significant results. Dialys. dur.: dialysis duration, CRP: C-reactive protein, KT/V1: an index for dialysis treatment adequacy, HTR1A_C: serotonin 1A receptor polymorphism (CC type), BDNF-G: brain derived neurotrophic factor polymorphism (GG type), FKBP5_T: glucocorticoid receptor polymorphism (TT type)

$\mathrm{p}=0.038)$ and mental $(\mathrm{B}=51.145, \mathrm{p}=0.010)$ QoL level. No significant association was found between the other genetic polymorphisms, clinical characteristics, and the QoL level in ESRD patients.

\section{DISCUSSION}

In this study, a polymorphism in HTR1A was found to be significantly associated with mental and physical QOL in ESRD patients. Patients with the CC genotype of the SNP (rs6295) in the promoter region of HTR1A gene had a significantly higher QoL level than patients with the GG/GC genotypes. This finding suggests that patients with the HTR1A G allele may suffer from a reduced QoL. The $\mathrm{G}$ allele has mostly been associated with an increased vulnerability to psychological distress, such as depression, anxiety and chronic stress, ${ }^{23-25}$ even thoughprevious studies that have investigated the role of HTR1A polymorphisms in psychological distress have reported mixed results in healthy volunteers and clinical patient samples. In support of these findings, several studies have reported that carriers of the $G$ allele respond less well to antidepressant treatment. ${ }^{26,27}$ The $\mathrm{G}$ allele also appears to be associated with higher neuroticism scores on the NEO personality inventory (NEO-PI-R), mainly due to associations with the anxiety and depression facets of neuroticism. ${ }^{7}$ In addition, several recent studies reported the emotional and behavioral characteristics of individuals with $\mathrm{G}$ alleles. One study demonstrated that the HTR1A rs $6295 \mathrm{G}$ allele is correlated with enhanced threat-related information processing, which confers vulnerability to stress-related psychiatric disorders. ${ }^{28}$ Furthermore, an HTR1A polymorphism was reported to be as- sociated with attenuated serotonergic tone and to affect pain perception. ${ }^{29}$ Therefore, the HTR $1 A$ rs $6295 \mathrm{G}$ allele may have a negative impact on the capacity of ESRD patients to cope with chronic stress and pain, and ultimately lower their QoL.

In contrast to the result from HTR1A, polymorphism in $B D N F$ and FKBP5 did not show any significant associations in this study. Previousgenetic studydid not find significant effects of serotonin transporter or BDNF Val66Met genetic polymorphism on major depression among the hemodialysis patient. ${ }^{13}$ Our work has contributed to find a stress-related genetic polymorphism in ESRD patients by revealing the unique effect of polymorphism in serotonin $1 \mathrm{~A}$ receptor on their quality of life. Considering previous research, HTR1A has been reported to be associated with many quality-of-life domains, such as disease-related pain, pain perception, ${ }^{29,30}$ depression, ${ }^{31-33}$ and chronic fatigue, ${ }^{34}$ while the genes $B D N F$ and FKBP5 have a comparatively limited effect on QoL. ${ }^{35}$ This may be one explanation for our result, but the difference between genetic polymorphisms in their effect on QoL requires further study.

Age, depression, medical comorbidity, and HTR1A polymorphism were revealed to have significant associations with the quality of life of ESRD patientsin the final regression analysis.Older age was associated with a lower QoL, and this finding has already been mentioned in a study of the general population, and studies of ESRD patients. ${ }^{36}$ Age has mostly been suggested as one of the main determinants of QoL that is not associated with renal disease, nor intensified by $\mathrm{it}^{37}$ although there have been other inconsistent result. ${ }^{38}$ We also found that QoL was negatively affected by depression in hemodialysis patients. This result is in line with previous studies, which suggested that a depressed mood may lead to a less favorable perception about 
their life, and thus the reporting of a lower quality of life. ${ }^{39,40}$

Other clinical factors were also correlated with QoL in ESRD patientsin this study. An increased level of high density lipoprotein, which is known to be positively associated with a decreased risk of heart disease, ${ }^{41}$ was correlated with health related QoL Level. Previous study also reported lower healthrelated QoL level in people with metabolic syndrome. ${ }^{42}$ QoL level was also negatively correlated with the level of CRP. This may be interpreted as an elevation in CRP level due to stress reaction ${ }^{4}$ or a reduced QoL due to a worsening of medical condition. ${ }^{36}$ There were other correlations between QoL and the number of co-morbid illnesses, and with the duration of hemodialysis, which have both been reported to affect the QoL of ESRD patients. ${ }^{43,44}$

As mentioned above, the quality of life of ESRD patients was influenced by many clinical characteristics. It is reasonable to assume that the patients' quality of life depends upon a complex interaction of multiple factors, such as disease outcome, personal traits, coping behavior, social support, and the quality of the care received. ${ }^{44}$ In this regard, if clinicians could detect and support the ESRD patients who are more vulnerable to prolonged stress exposure, it would be helpful for preventing progression to stress-related psychiatric illnesses.

This study has three limitations. Firstly, the small sample size, which reduced the statistical power, which may have been insufficient to detect direct correlations between depression, anxiety and genetic polymorphisms. Secondly, various comorbidities of ESRD patients that could have affected psychological status, depending on their biological impact, were not sufficiently controlled in analyzing and interpreting the data. Thirdly, the present study only examined quantitative self-reported distress levels and did not classify phenotypes into clinical mental disorders by using a structured clinical interview with diagnostic and statistical manual for mental disorders. History of psychiatric medication use was not gathered, either. In order to validate our findings it would be necessary to recruit a more homogenous group of patients, to control for other physical and psychiatric illnesses.

In summary, we investigated the relationship between health-related QoL and clinical characteristics and genetic polymorphism in ESRD patients. After controlling multiple clinical variables, polymorphism in serotonin $1 \mathrm{~A}$ receptor, as well as age and depression, was significantly associated with physical and mental QoL in hemodialysis patients. Functional activity in the serotonin receptor system may have a modulating effect on QoL in hemodialysis patients. Clinicians should pay more attention to the genetic traits of hemodialysis patients, as well as to their age and emotional distress, to improve their health-related QoL.

\section{Acknowledgments}

All authors have no conflict of interest. Some of the results of this study were presented as a new research poster at the 167th Annual meeting of American Psychiatric Association in New York in 2014.

This study was supported by a grant of the Korean Mental Health Technology R\&D Project, Ministry of Health \& Welfare, Republic of Korea (HM15C1189).

\section{REFERENCES}

1. Kimmel PL, Peterson RA. Depression in end-stage renal disease patients treated with hemodialysis: tools, correlates, outcomes, and needs. Semin Dial 2005;18:91-97.

2. Kimmel PL, Cukor D, Cohen SD, Peterson RA. Depression in endstage renal disease patients: a critical review. Adv Chronic Kidney Dis 2007;14:328-334.

3. Manns B, Johnson J, Taub K, Mortis G, Ghali W, Donaldson C. Quality of life in patients treated with hemodialysis or peritoneal dialysis: what are the important determinants? Clin Nephrol 2003;60:341-351.

4. Howren MB, Lamkin DM, Suls J. Associations of depression with Creactive protein, IL-1, and IL-6: a meta-analysis. Psychosom Med 2009; 71:171-186.

5. Neumeister A, Young T, Stastny J. Implications of genetic research on the role of the serotonin in depression: emphasis on the serotonin type $1 \mathrm{~A}$ receptor and the serotonin transporter. Psychopharmacology (Berl) 2004;174:512-524.

6. Lemonde S, Turecki G, Bakish D, Du L, Hrdina PD, Bown CD, et al. Impaired repression at a 5-hydroxytryptamine $1 \mathrm{~A}$ receptor gene polymorphism associated with major depression and suicide. J Neurosci 2003;23:8788-8799.

7. Strobel A, Gutknecht L, Rothe C, Reif A, Mössner R, Zeng Y, et al. Allelic variation in 5-HT1A receptor expression is associated with anxiety-and depression-related personality traits. J Neural Transm (Vienna) 2003;110:1445-1453.

8. Verhagen M, van der Meij A, van Deurzen P, Janzing JG, Arias-Vasquez A, Buitelaar J, et al. Meta-analysis of the BDNF Val66Met polymorphism in major depressive disorder: effects of gender and ethnicity. Mol Psychiatry 2008;15:260-271.

9. Choi MJ, Kang RH, Lim SW, Oh KS, Lee MS. Brain-derived neurotrophic factor gene polymorphism (Val66Met) and citalopram response in major depressive disorder. Brain Res 2006;1118:176-182.

10. Kang R, Chang H, Wong M, Choi M, Park J, Lee H, et al. Brain-derived neurotrophic factor gene polymorphisms and mirtazapine responses in Koreans with major depression. J Psychopharmacol 2010;24:1755-1763.

11. Kang JI, Chung HC, Jeung HC, Kim SJ, An SK, Namkoong K. FKBP5 polymorphisms as vulnerability to anxiety and depression in patients with advanced gastric cancer: a controlled and prospective study. Psychoneuroendocrinology 2012;37:1569-1576.

12. Lekman M, Laje G, Charney D, Rush AJ, Wilson AF, Sorant AJ, et al. The FKBP5 Gene in Depression and Treatment Response-an Association Study in the Sequenced Treatment Alternatives to Relieve Depression (STAR* D) Cohort. Biol Psychiatry 2008;63:1103-1110.

13. Wang LJ, Chen CK, Hsu HJ, Wu IW, Sun CY, Lee CC. Depression, 5HTTLPR and BDNF Val66Met polymorphisms, and plasma BDNF levels in hemodialysis patients with chronic renal failure. Neuropsychiatr Dis Treat 2014;10:1235-1241.

14. Ulusoy S, Gungor E, Gul S, Ozkan G, Karahan SC, Sit D, et al. Do hemodialysis adequacy data reflect reality? Artif Organs 2013;37:189-195.

15. Jenkinson C, Coulter A, Wright L. Short form 36 (SF36) health survey questionnaire: normative data for adults of working age. BMJ 1993; 306:1437-1440.

16. Ware JE Jr, Gandek B. Overview of the SF-36 Health Survey and the International Quality of Life Assessment (IQOLA) Project. J Clin Epidemiol 1998;51:903-912.

17. Han CW, Lee EJ, Iwaya T, Kataoka H, Kohzuki M. Development of the 
Korean Version of Short-Form 36-Item Health Survey: Health Related QOL of Healthy Elderly People and Elderly Patients in Korea. Tohoku J Exp Med 2004;203:189-194.

18. Nam BH, Lee SW. Testing the validity of the Korean SF-36 health survey. J Korean Soc Health Stat 2003;28:3-24.

19. Zigmond AS, Snaith RP. The hospital anxiety and depression scale. Acta Psychiatr Scand 1983;67:361-370.

20. Bjelland I, Dahl AA, Haug TT, Neckelmann D. The validity of the Hospital Anxiety and Depression Scale. An updated literature review. J Psychosom Res 2002;52:69-77.

21. Oh SM, Min KJ, Park DB. A study on the standardization of the hospital anxiety and depression scale for Koreans: a comparison of normal, depressed and anxious groups. J Korean Neuropsychiatr Assoc 1999; 38:289-296

22. Zou YF, Wang Y, Liu P, Feng XL, Wang BY, Zang TH, et al. Association of BDNF Val66Met polymorphism with both baseline HRQOL scores and improvement in HRQOL scores in Chinese major depressive patients treated with fluoxetine. Hum Psychopharmacol Clin 2010;25:145-152.

23. Parsey RV, Oquendo MA, Ogden RT, Olvet DM, Simpson N, Huang YY, et al. Altered serotonin 1A binding in major depression: a [carbonyl-C-11] WAY100635 positron emission tomography study. Biol Psychiatry 2006;59:106-113.

24. Richardson-Jones JW, Craige CP, Guiard BP, Stephen A, Metzger KL, Kung HF, et al. 5-HT1A autoreceptor levels determine vulnerability to stress and response to antidepressants. Neuron 2010;65:40-52.

25. Rothe C, Gutknecht L, Freitag C, Tauber R, Mossner R, Franke P, et al. Association of a functional-1019C $>$ G 5-HT1A receptor gene polymorphism with panic disorder with agoraphobia. Int J Neuropsychopharmacol 2004;7:189-192.

26. Hong C, Chen T, Yu YW, Tsai S. Response to fluoxetine and serotonin $1 \mathrm{~A}$ receptor (C-1019G) polymorphism in Taiwan Chinese major depressive disorder. Pharmacogenomics J 2005;6:27-33.

27. Yu YW, Tsai SJ, Liou YJ, Hong CJ, Chen TJ. Association study of two serotonin $1 \mathrm{~A}$ receptor gene polymorphisms and fluoxetine treatment response in Chinese major depressive disorders. Eur Neuropsychopharmacol 2006;16:498-503.

28. Mekli K, Payton A, Miyajima F, Platt H, Thomas E, Downey D, et al. The HTR1A and HTR1B receptor genes influence stress-related information processing. Eur Neuropsychopharmacol 2011;21:129-139.

29. Lindstedt F, Lonsdorf TB, Schalling M, Kosek E, Ingvar M. Perception of thermal pain and the thermal grill illusion is associated with polymorphisms in the serotonin transporter gene. PLoS One 2011;6:e17752.

30. Lindstedt F, Karshikoff B, Schalling M, Olgart Höglund C, Ingvar M, Lekander M, et al. Serotonin-1A receptor polymorphism (rs6295) associated with thermal pain perception. PLoS One 2012;7:e43221.
31. Amin N, Hottenga JJ, Hansell NK, Janssens AC, de Moor MH, Madden PA, et al. Refining genome-wide linkage intervals using a metaanalysis of genome-wide association studies identifies loci influencing personality dimensions. Eur J Hum Genet 2013;21:876-882.

32. Kim HN, Roh SJ, Sung YA, Chung HW, Lee JY, Cho J, et al. Genomewide association study of the five-factor model of personality in young Korean women. J Hum Genet 2013;10:667-674.

33. Sloan JA, Zhao CX. Genetics and quality of life. Curr Probl Cancer 2006;30:255-260.

34. Ortega-Hernandez OD, Cuccia M, Bozzini S, Bassi N, Moscavitch S, Diaz-Gallo LM, et al. Autoantibodies, Polymorphisms in the Serotonin Pathway, and Human Leukocyte Antigen Class II Alleles in Chronic Fatigue Syndrome. Ann N Y Acad Sci 2009;1173:589-599.

35. Sprangers MA, Thong MS, Bartels M, Barsevick A, Ordoñana J, Shi Q, et al. Biological pathways, candidate genes, and molecular markers associated with quality-of-life domains: an update. Qual Life Res 2014; 23:1997-2013.

36. Rebollo P, Ortega F, Baltar JM, Díaz-Corte C, Navascués RA, Naves M, et al. Health-related quality of life (HRQOL) in end stage renal disease (ESRD) patients over 65 years. Geriatr Nephrol Urol 1998;8:85-94.

37. Neves P. Chronic haemodialysis in elderly patients. Neprhol Dial Transpl 1995;10(Suppl 6):69-71.

38. Morgan B. The relationship between chronological age and perceived quality of life of hemodialysis patients. ANNA J 1990;17:63-66, discussion 67.

39. Amato M, Ponziani G, Rossi F, Liedl C, Stefanile C, Rossi L. Quality of life in multiple sclerosis: the impact of depression, fatigue and disability. Mult Scler 2001;7:340-344.

40. Wells KB, Stewart A, Hays RD, Burnam MA, Rogers W, Daniels M, et al. The functioning and well-being of depressed patients: results from the Medical Outcomes Study. JAMA 1989;262:914-919.

41. Castelli WP, Doyle JT, Gordon T, Hames CG, Hjortland MC, Hulley SB, et al. HDL cholesterol and other lipids in coronary heart disease. The cooperative lipoprotein phenotyping study. Circulation 1977;55:767-772.

42. Jahangiry L, Shojaeezadeh D, Montazeri A, Najafi M, Mohammad K. Health-related quality of life among people participating in a metabolic syndrome e-screening program: a web-based study. Int J Prev Med 2016;7:27.

43. Kimmel PL, Emont SL, Newmann JM, Danko H, Moss AH. ESRD patient quality of life: symptoms, spiritual beliefs, psychosocial factors, and ethnicity. Am J Kidney Dis 2003;42:713-721.

44. Merkus MP, Jager KJ, Dekker FW, Boeschoten EW, Stevens P, Krediet RT. Quality of life in patients on chronic dialysis: self-assessment 3 months after the start of treatment. The Necosad Study Group. Am J Kidney Dis 1997;29:584-592. 